\title{
Effects of Influential Parameters on Long-Term Channel Evolution Following Low-Head Dam Construction and Removal
}

\author{
Sinae Kim¹, Yuji Toda ${ }^{2}$ \\ ${ }^{1}$ Department of Land, Water and Environment Research, Korea Institute of Civil Engineering and Building Technology, \\ Goyang-si, Korea \\ ${ }^{2}$ Department of Civil Engineering, Nagoya University, Nagoya, Japan \\ Email: flowerksn@hotmail.com
}

How to cite this paper: Kim, S. and Toda, Y. (2018) Effects of Influential Parameters on Long-Term Channel Evolution Following Low-Head Dam Construction and Removal. Journal of Water Resource and Protection, 10, 780-793.

https://doi.org/10.4236/jwarp.2018.108044

Received: July 27, 2018

Accepted: August 17, 2018

Published: August 20, 2018

Copyright $\odot 2018$ by authors and Scientific Research Publishing Inc. This work is licensed under the Creative Commons Attribution International License (CC BY 4.0).

http://creativecommons.org/licenses/by/4.0/

\begin{abstract}
The long-term existence of dam structures significantly modified the river channel. In accordance with a drastic increase of low-head dams under consideration for removal in recent years, it is important to predict the effects of low-head dam removal from the modified river channel by the low-head dam construction. This study intends to investigate the long-term channel evolution process following low-head construction and removal and to find out the influential parameters (sediment diameter, river bed slope, dam height) for those channel evolution by two-dimensional numerical simulation model. Following the low-head dam construction, sediment deposition rates in upstream of the low-head dam are varied with the influential parameters. The sediment deposition rates and sandbar formation with riparian vegetation settlement on sandbars have significantly affected for channel evolution following low-head dam removal. Especially the knickpoint formation and the types of vegetation (grass type and tree type) on the sandbars are critical factors for channel evolution following low-head dam removal. Through the numerical simulation results of low-head dam construction (50 years) and low-head dam removal (50 years), it is identified that the modified river channel by low-head dam may not be easily restored to pre-dam conditions following its removal especially in river geomorphology and riparian vegetation. Consequently, this study found that the reversibility following low-head dam construction and removal depends on the sediment deposition rates in upstream of the low-head dam.
\end{abstract}

\section{Keywords}

Low-Head Dam, Dam Construction, Dam Removal, Channel Evolution, 
Influential Parameter

\section{Introduction}

Dam structures obstruct a connectivity of river corridor affecting river ecosystem. However, these dam structures are indispensable elements in river for water resources and flood control. The long-term existence of dam structures affects structure and function of river ecosystem [1] with modification of flow and sediment flux. Especially, abandoned dam structures can cause serious problems for flood safety and river ecosystem. Thus, it is necessary to remove the dam structure as soon as the end of function or life span of dam structures.

Since there was a huge number of dam construction works until 1980s, the number of dam structures completed their life span or function has been drastically increasing in recent years. However, studies for low-head dam removal are insufficient to predict the effects of low-head dam removal with lack of quantitative methods. A few studies have investigated and documented short-term geomorphic changes following low-head dam removal. Reference [2] established channel evolution model to explain channel development in a reservoir following dam removal adapted from Reference [3] channel evolution model for incising channel.

Once riparian vegetation begins to establish on the river channel, the riparian vegetation also can affect the fluvial processes as well [4]. Therefore, it is important to investigate fluvial processes along with the riparian vegetation establishment. Reference [5] suggested a numerical simulation model to predict both geomorphic and riparian vegetation changes following the low-head dam removal.

Using the two-dimensional numerical simulation model [5], this study intends to investigate the long-term channel evolution process following low-head construction and removal and to find out influential parameters on channel evolution following low-head dam removal. The critical parameters considering for this study are dam height, sediment diameter, and river bed slope.

\section{Numerical Simulation Model}

The numerical simulation model calculates the depth-averaged flow, bed load transport and bed elevation change in flood stage with the destruction of riparian vegetation. In ordinary stage, riparian vegetation invasion, growth and expansion are calculated in this numerical model (Figure 1). Initial river bed morphology, sediment diameter and discharge are necessary for calculation as input data.

\subsection{Flow and Sediment Transport Model}

In flood stage, the water depth and depth-averaged flow velocity are calculated 


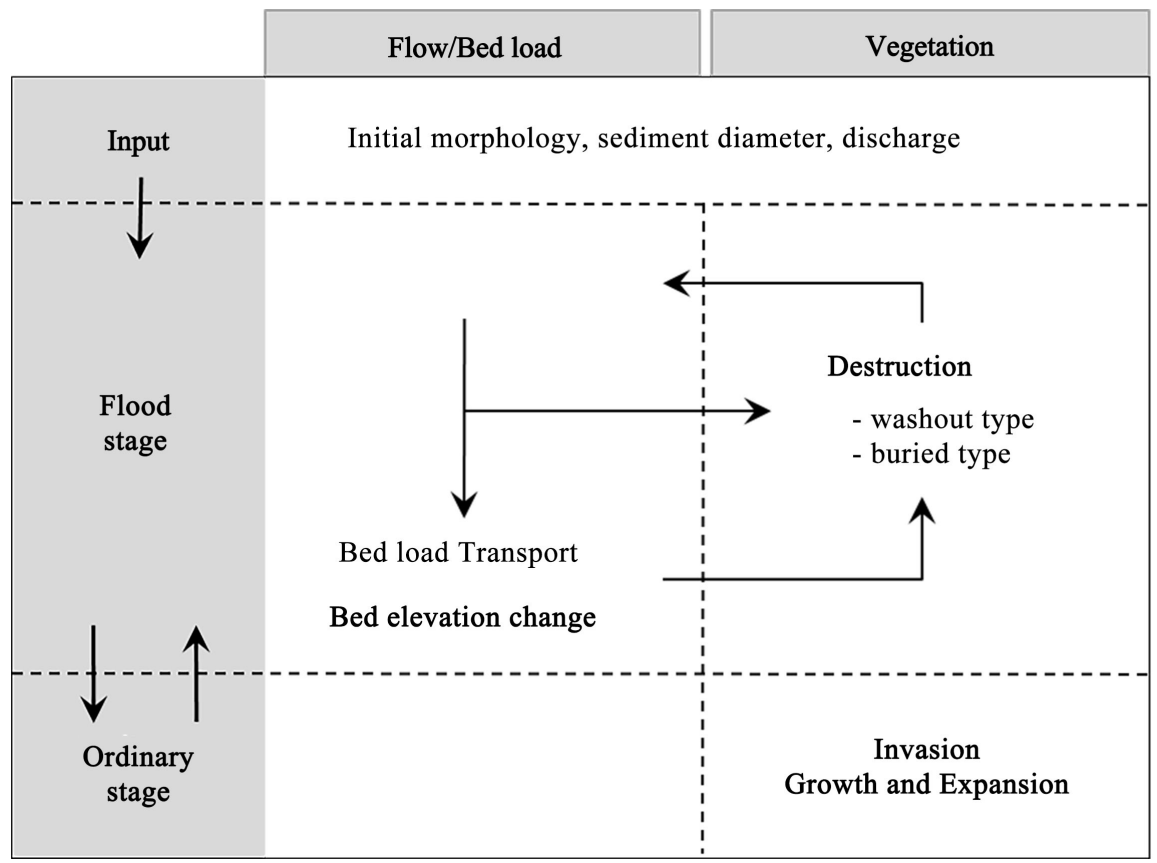

Figure 1. Numerical simulation model flow [5].

by shallow water equation. The bottom friction is calculated by Manning's resistance law. Riparian vegetation effects on flood flow are represented by employing drag formula.

$$
\begin{gathered}
\tau_{b i}=\frac{\rho g n^{2} V_{i} \sqrt{u^{2}+v^{2}}}{h^{1 / 3}} \\
F_{i}=\frac{\rho C_{D} \chi l V_{i} \sqrt{u^{2}+v^{2}}}{2}
\end{gathered}
$$

where $V_{i}: u$ when $i=x, V_{\dot{i}}: v$ when $i=y, n$ : Manning roughness coefficient, $C_{D}$ : drag coefficient $(=1.0), \quad \chi$ : vegetation density parameter $(=0.02)$ and 1 : vegetation height in flow, respectively.

To calculate bed load transport rates in longitudinal and lateral direction, the MPM equation [6] and Hasegawa equation [7] are applied respectively.

$$
\begin{gathered}
\frac{\partial z_{b}}{\partial t}+\frac{1}{1-\lambda}\left[\frac{\partial q_{b x}}{\partial x}+\frac{\partial q_{b y}}{\partial y}\right]=0 \\
q_{b s}=8.0\left(\tau_{*}-\tau_{*_{c}}\right)^{1.5} \sqrt{R_{s} g d^{3}} \\
q_{b n}=q_{b s}\left(\frac{h}{r} N_{*}-\sqrt{\frac{\tau_{*_{c}}}{\mu_{s} \mu_{k} \tau_{*}}} \frac{\partial z_{b}}{\partial n}\right)
\end{gathered}
$$

where $q_{b x}, q_{b y}$ : bed load transport rate in $x$ and $y$ direction, $\lambda$ : bed porosity, $q_{b s}$ : longitudinal bed load transport rate, $q_{b n}$ : lateral bed load transport rate, $\tau_{*}$ : critical tractive force, $\tau_{*_{c}}$ : dimensionless critical tractive force, $R_{s}:$ specific gravity of bed load, $d$ : diameter of sediment, $r$. streamline curvature of radius, $N_{*}$ : constant value for secondary flow strength $(=7.0), \mu_{s}:$ static friction coeffi- 
cient, $\mu_{k}$ : kinetic friction coefficient and $n$ : Manning roughness coefficient, respectively.

\subsection{Treatment of Low-Head Dam}

If there is a low-head dam, the bed load will be transported to downstream when the sediment deposition height in upstream of dam reaches to the same height of the low-head dam (Figure 2(b)). Unless upstream of the low-head dam is fully deposited as high as the low-head dam, there is no bed load transport across the low-head dam (Figure 2(a)).

\subsection{Vegetation Model}

The numerical simulation model calculates the growth, expansion and invasion of riparian vegetation (grass type, tree type) in ordinary stage. It is assumed that the higher vegetation can take more light for photosynthesis for the interspecific competition [8]. The growth of riparian vegetation is calculated by the balance of primary production and respiration [9]. The horizontal expansion of riparian vegetation is formulated by diffusion type formula in the growth equation. The equation for growth of the riparian vegetation is given by:

$$
\frac{\partial M_{i}}{\partial t}=P_{i}-R_{i}+\frac{\partial}{\partial x}\left(k_{x i} \frac{\partial M_{i}}{\partial x}\right)+\frac{\partial}{\partial y}\left(k_{y i} \frac{\partial M_{i}}{\partial y}\right)
$$

where $M_{i}$ : biomass per unit area, $P_{i}$ : primary production, $R_{i}$ : respiration, $k_{x i}$, $k_{y i}$ : the diffusion coefficients for horizontal expansion of vegetation in $x$ and $y$ directions, respectively $(=4.0 / 2.0)$. The subscript $i$ denotes the index identifying the grass $(g)$ and tree $(t)$ types of vegetation

In order to simulate the invasion of riparian vegetation at the interface between water body and the surrounding upland, the invasion possible area is estimated from the differences with ordinary water level and averaged water level of seed dispersal season. The riparian vegetation is settled in the bare ground if the bare ground has not experienced morphological disturbance for $T_{i}$ years. Based on the analysis of reference case study (Gongreung River), the required time for settlement $T_{i}$ is determined as $T_{g}=1$ year for grass type and $T_{t}=5$ years for tree type, respectively. The initial biomass on the vegetation settlement area is given by:

$$
M_{i}=\frac{z_{0}-z}{z_{0}} M_{i 0}+M_{i 0 \min }
$$

in which $z$. relative height from the ordinary water stage, $z_{0}$ : relative height of the water level of the seed dispersal season from the ordinary water stage, $M_{i 0}$ : initial biomass at the water edge of the ordinary water stage $(=114.0)$ and $M_{i 0 \min }$ : initial biomass at $z=z_{0} \quad(=6.0)$, respectively (Figure 3).

There are two different ways (wash out, buried) to decide the destruction of the riparian vegetation in flood stage. The wash out destruction is occurred either if the local scour depth during flood becomes larger than the root depth or 


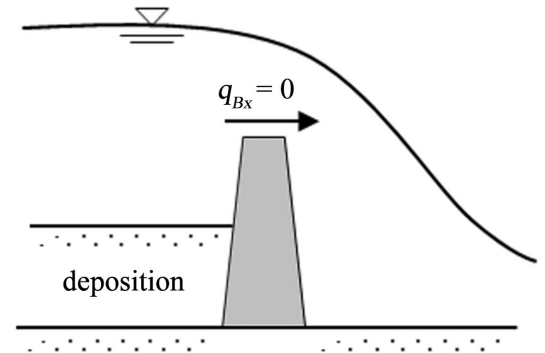

(a)

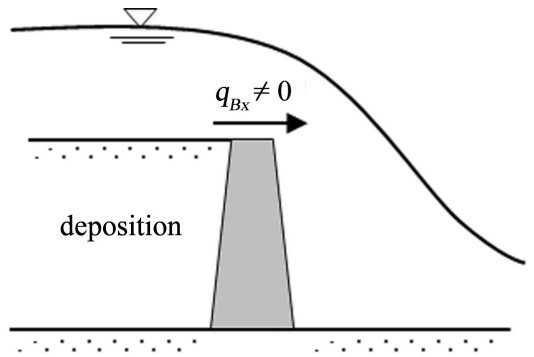

(b)

Figure 2. Assumptions for bed load transport for low-head dam construction. (a) $q_{B x}=0$; (b) $q_{B X} \neq 0$.

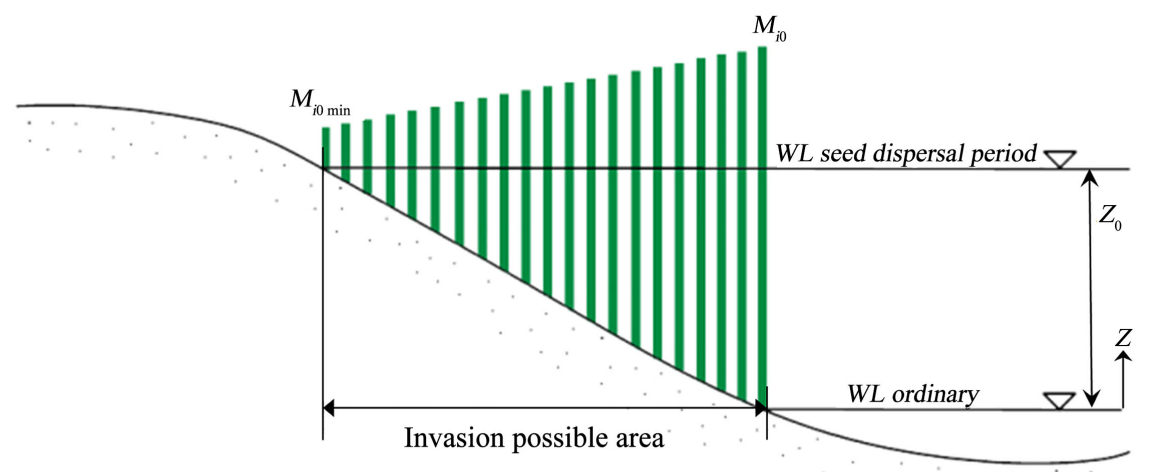

Figure 3. Modeling of vegetation invasion to bare ground [5].

if the bottom friction on the vegetation stand exceeds critical wash out shear stress for vegetation [10]. The buried type destruction takes place when the sediment deposition depth is higher than vegetation height. Also the buried type destruction calculated the vegetation biomass depend on the vegetation height from ground due to the bed elevation changes during flood.

\subsection{Computational Conditions}

Simplified channel designed for the simulation is $50 \mathrm{~m}$ in width $1000 \mathrm{~m}$ in length (Figure 4). On the point of $700 \mathrm{~m}$ from upstream end, the low-head dam is located. The unit grid size is $5 \mathrm{~m}$ in length and width. The boundary conditions for the numerical calculation are decided by referring the case of Gongreung River (averaged river width $70 \mathrm{~m}$ [5]). Averaged annual maximum discharge is designed as $300 \mathrm{cms}$ and occurred once in a year. The ordinary discharge is designed as $2 \mathrm{cms}$.

To find the influential parameters and channel evolution processes, the numerical simulations have been performed through the 2 stages of low-head dam construction (stage I) and low-head dam removal (stage II) (Table 1). In stage I, the numerical model has simulated with a low-head dam. The simulations have been conducted for 50 years considering the life span of a low-head dam structure. Stage II is performed to identify the low-head dam removal effects. The initial conditions is the final results of stage I (50 years) extracting the 

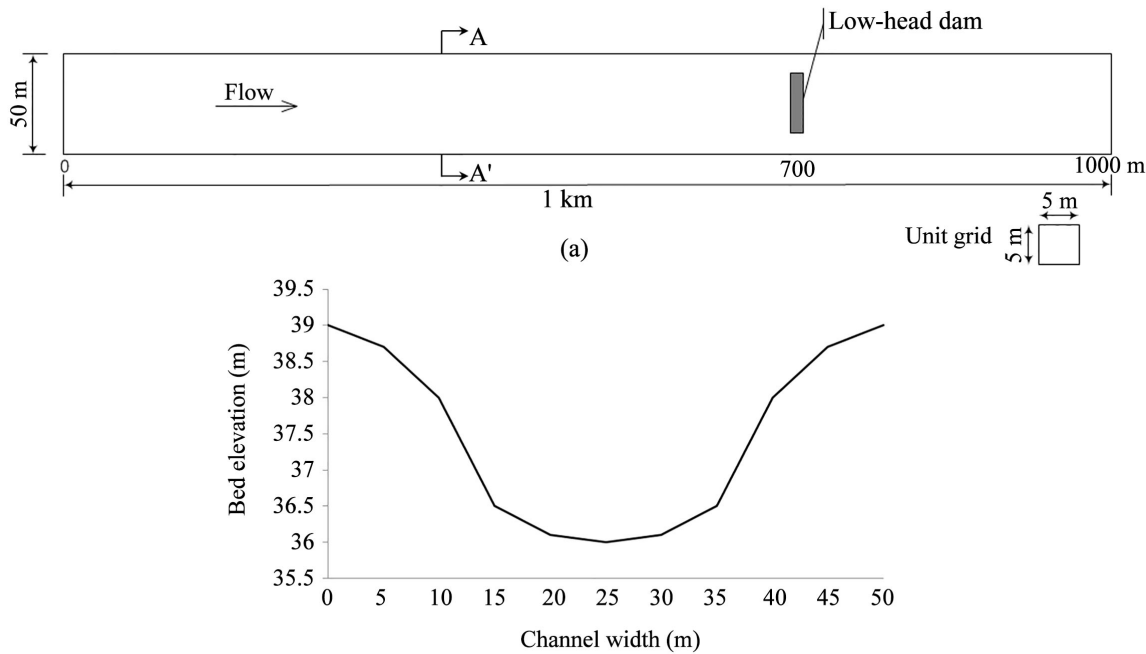

(b)

Figure 4. Channel design for numerical simulation. (a) Horizontal plan; (b) Cross section $\mathrm{A}-\mathrm{A}^{\prime}(\mathrm{X}=400)$.

Table 1. Conditions for numerical simulation.

\begin{tabular}{cccccc}
\hline Stage & Dam height & River slope & Diameter & Time (yrs) & No. \\
\hline $\begin{array}{c}\text { I } \\
\begin{array}{c}\text { Low-head dam } \\
\text { Construction) }\end{array}\end{array}$ & $1.5 \mathrm{~m}$ & $1 / 200$ & $2 \mathrm{~mm}$ & 50 & $\mathrm{D}-1$ \\
& $1.5 \mathrm{~m}$ & $1 / 200$ & $5 \mathrm{~mm}$ & 50 & $\mathrm{D}-2$ \\
& $2.0 \mathrm{~m}$ & $1 / 300$ & $2 \mathrm{~mm}$ & 50 & $\mathrm{D}-3$ \\
$\begin{array}{c}\text { II } \\
\text { (Low-head dam } \\
\text { removal })\end{array}$ & $1.5 \mathrm{~m}$ & $1 / 200$ & $2 \mathrm{~mm}$ & 50 & $\mathrm{R}-1$ \\
& $1.5 \mathrm{~m}$ & $1 / 200$ & $5 \mathrm{~mm}$ & 50 & $\mathrm{R}-2$ \\
& $2.0 \mathrm{~m}$ & $1 / 200$ & $2 \mathrm{~mm}$ & 50 & $\mathrm{R}-4$ \\
\hline
\end{tabular}

low-head dam. Three parameters (dam height, river bed slope and sediment diameter) which can be influential for channel evolution following low-head dam construction and removal are chosen for this study based on previous studies.

\section{Results}

\subsection{Low-Head Dam Construction}

\subsubsection{Long-Term Effects of Low-Head Dam Construction}

The construction of a low-head dam and its long-term existence in the river channel substantially alter river hydraulic features, sediment transport rates, and river geomorphology. The numerical model has been simulated with the low-head dam for 50 years to clarify the long-term effects of low-head dam construction with a low-head dam installation in the river channel. By the low-head 
dam construction, backwater pool is made in the upstream of the low-head dam (Figure 5). The backwater pool by a low-head dam construction induces sediment deposition in the upstream of the dam structure according to the reduction of flow velocity. A delta is formed in the upstream of the low-head dam with continuous sediment input. The sediment deposits onto the delta expanding topset, avalanching foreset [11] [12] [13] [14], and forming the bottomset layer beyond the foreset toe. As a result of numerical simulation for 50 years with the low-head dam construction, the topset delta is steadily expanding toward the dam structures with gradual reduction of the longitudinal length of the bottomset. The retention of sediment in the upstream reservoir causes significant reduction of sediment transport rates to downstream of the low-head dam. In downstream of the low-head dam, a plunge pool is created by the local scour in just below the low-head dam with increase of erosive power by head drop. Over the long-term period with a low-head dam, the eroded sediment from the plunge pool deposited further downstream and created depositional bars. The depositional bars easily colonized by the riparian vegetation (grass type, tree type or both) with the low-head dam in the upstream.

\subsubsection{Influential Parameters}

The effects on upstream of the low-head dam are evident following a low-head dam construction. The sediment deposition in upstream begins from the upstream end of the backwater pool and gradually expands toward the dam with time sequence. As a result of numerical simulations, the sediment deposition characteristics on upstream reservoir have some differences depends on the parameters (sediment diameter, river bed slope and dam height). Figure 6 shows the longitudinal profile changes of sediment deposition on upstream of the low-head dam. The maximum height of sediment deposition on the topset is $0.78 \mathrm{~m}$ (D-1), $0.46 \mathrm{~m}$ (D-2), $0.41 \mathrm{~m}(\mathrm{D}-3)$ and $0.70 \mathrm{~m}$ (D-4) respectively. Also the length of the topset is reached as far as $490 \mathrm{~m}(\mathrm{D}-1), 390 \mathrm{~m}(\mathrm{D}-2), 310 \mathrm{~m}$ (D-3) and $405 \mathrm{~m}$ (D-4) respectively from upstream end. Based on the case D-1, sediment deposition rates on the topset considerably decreases with larger sediment diameter (5 mm, D-2) and gradual bed slope (1/300, D-3). The dam height also significantly influences on the sediment deposition onto the topset (D-4). The aspects of the foreset also have varied according to the changes of sediment diameter, river bed slope and dam height. The case of larger sediment $(5 \mathrm{~mm}$, $\mathrm{D}-2)$ has shown the longest length $(90 \mathrm{~m})$ of the foreset with gradual incline, while the case of smaller bed slope $(1 / 300, D-3)$ has formed steep incline with the shortest length $(15 \mathrm{~m})$ of the foreset. The bottomset of the case D-1 has reached to the dam structure causing some sediment deposition behind the dam because of the longest topset length.

\subsection{Effects of Low-Head Dam Removal}

\subsubsection{Low-Head Dam Removal Effects}

River channel development and evolution following dam removal are strongly 
governed by the characteristics of the deposited sediment in reservoir such as sediment diameter, cohesiveness, and consolidation, and vertical layering of sediment [2] [15] [16] [17] [18] [19]. The stored sediment in the upstream of the low-head dam frequently forms the knickpoint as soon as the low-head dam is removed. Stepped knickpoints (Head cut migration) take place during channel evolution following low-head dam removal in terms of cohesive, consolidated, or layered deposits [18].

From the results of numerical calculation for low-head dam removal, the knickpoints have been formed (Figure 7). In upstream of the removed dam, the primary knickpoint has been created by deposited sediment just after the low-head dam removal and gradually higher until 12 months after removal. After 15 months of low-head dam removal, the knickpoint has been dissipated as flat river bed. The upstream channel development with a kinckpoint caused the other knickpoint in downstream of the removed dam after 3 months of low-head dam removal with existing sand bar with riparian vegetation colonization including both grass and tree type. The secondary knickpoint also has had the peak height at 12 months after removal. Unlike the primary knickpoint without any trace after it disappears, the secondary knickpoint has been formed in the fore part of sandbar. This secondary knickpoint contributed to increase the height of sandbar colonized by riparian vegetation. With the knickpoints, Most of deposited sediment in upstream of dam transported to the downstream. The local scour just below the removed dam has been recovered with the restoration of sediment flux after low-head dam removal.

\subsubsection{Influential Parameters}

In order to identify the influential parameters for channel evolution after the low-head dam removal, the final (50 years) results of dam construction simulation for each case have been applied for low-head dam removal calculation as initial conditions except the low-head dam structure.

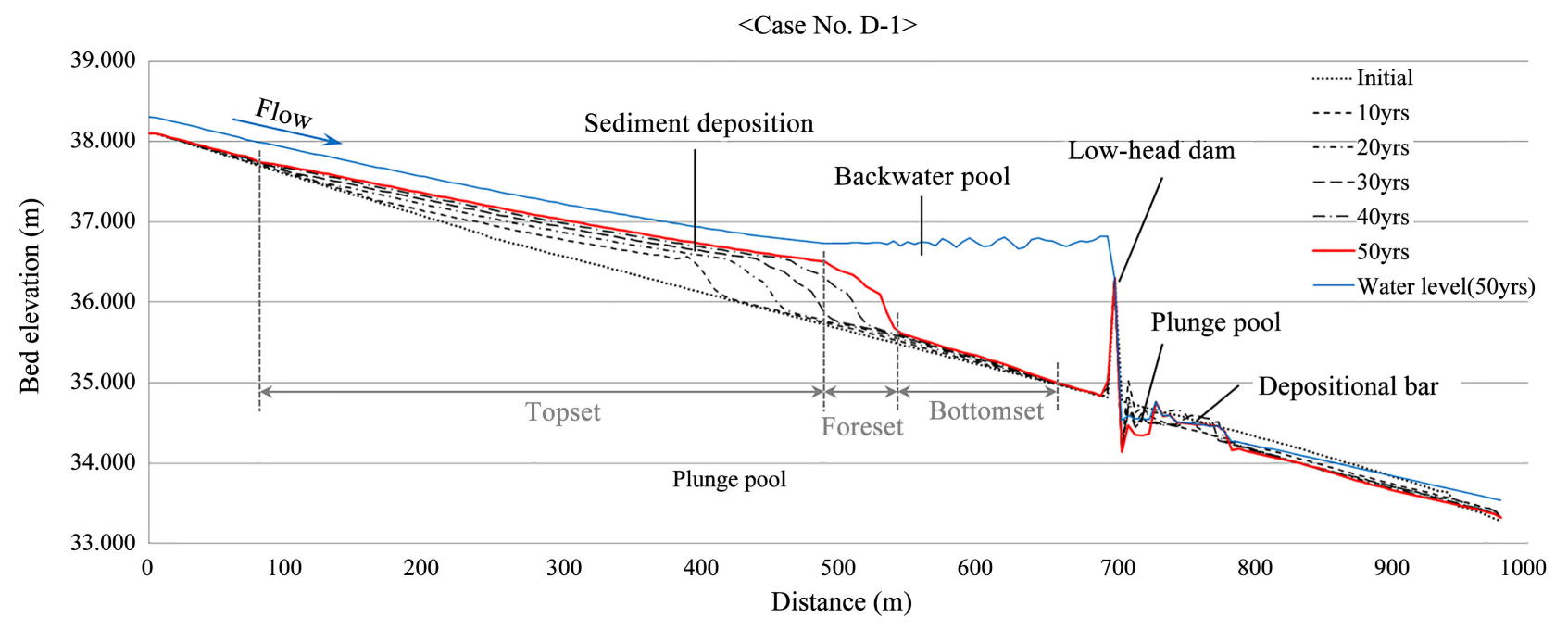

Figure 5. Long-term effects of low-head dam construction. 


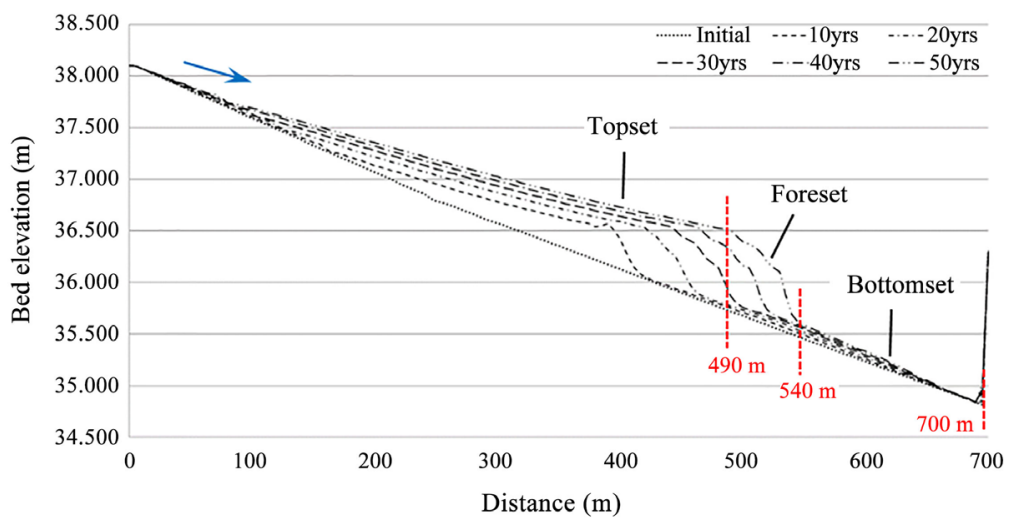

(a)

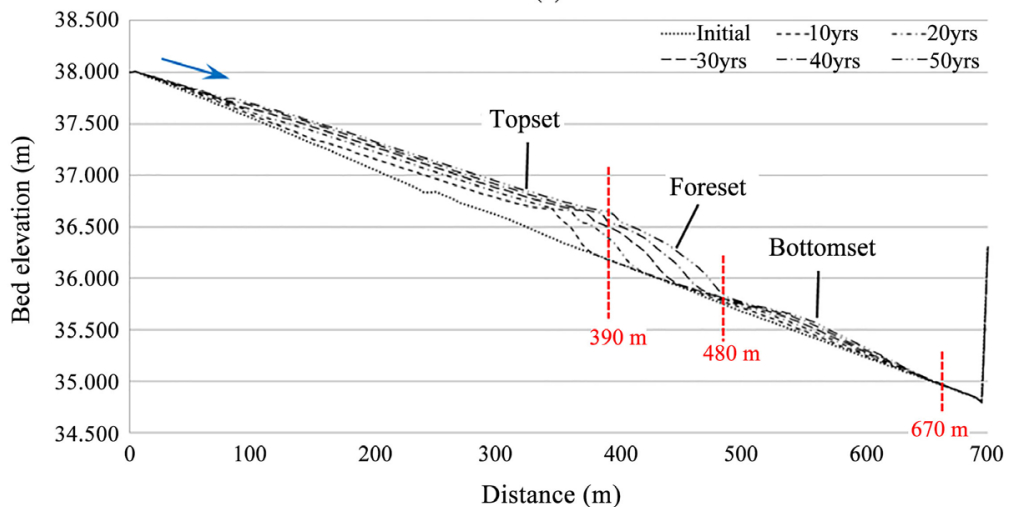

(b)

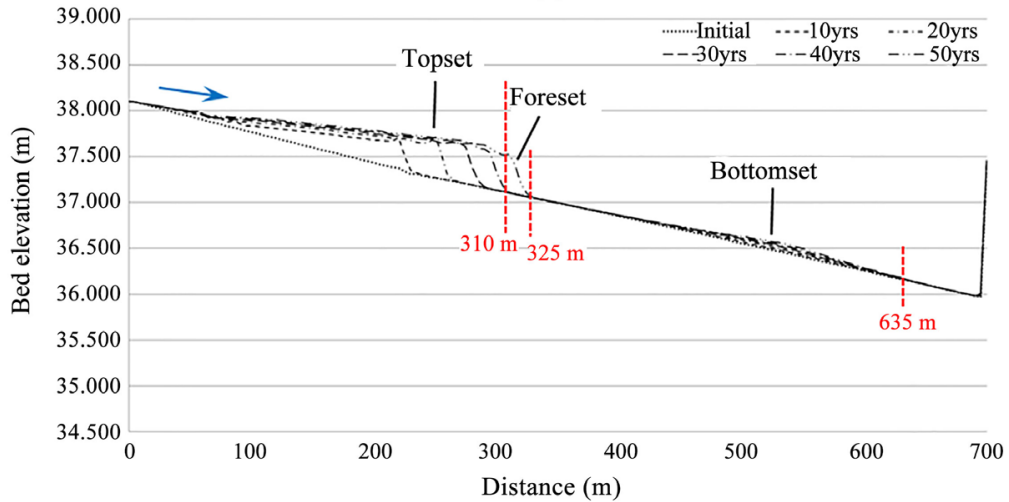

(c)

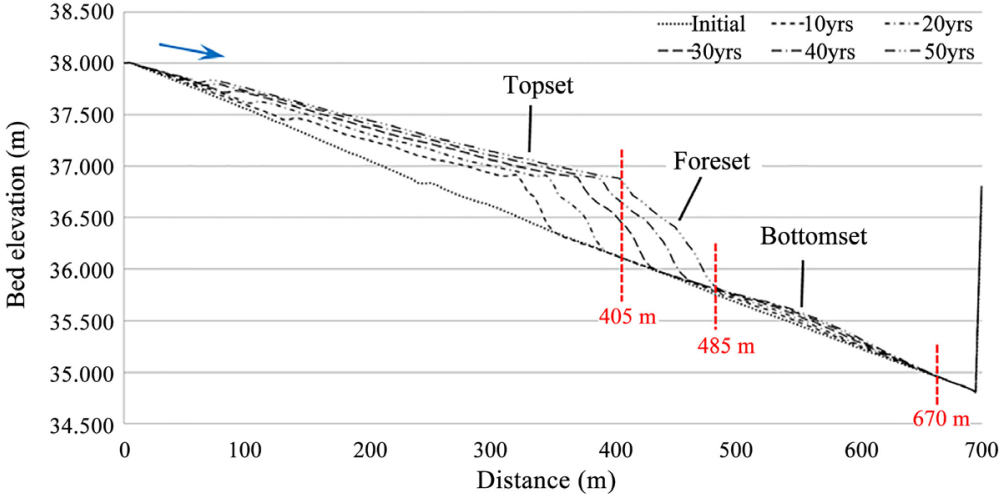

(d)

Figure 6. Longitudinal profile changes of upstream sediment deposition. (a) Case No. D-1; (b) Case No. D-2; (c) Case No. D-3; (d) Case No. D-4. 


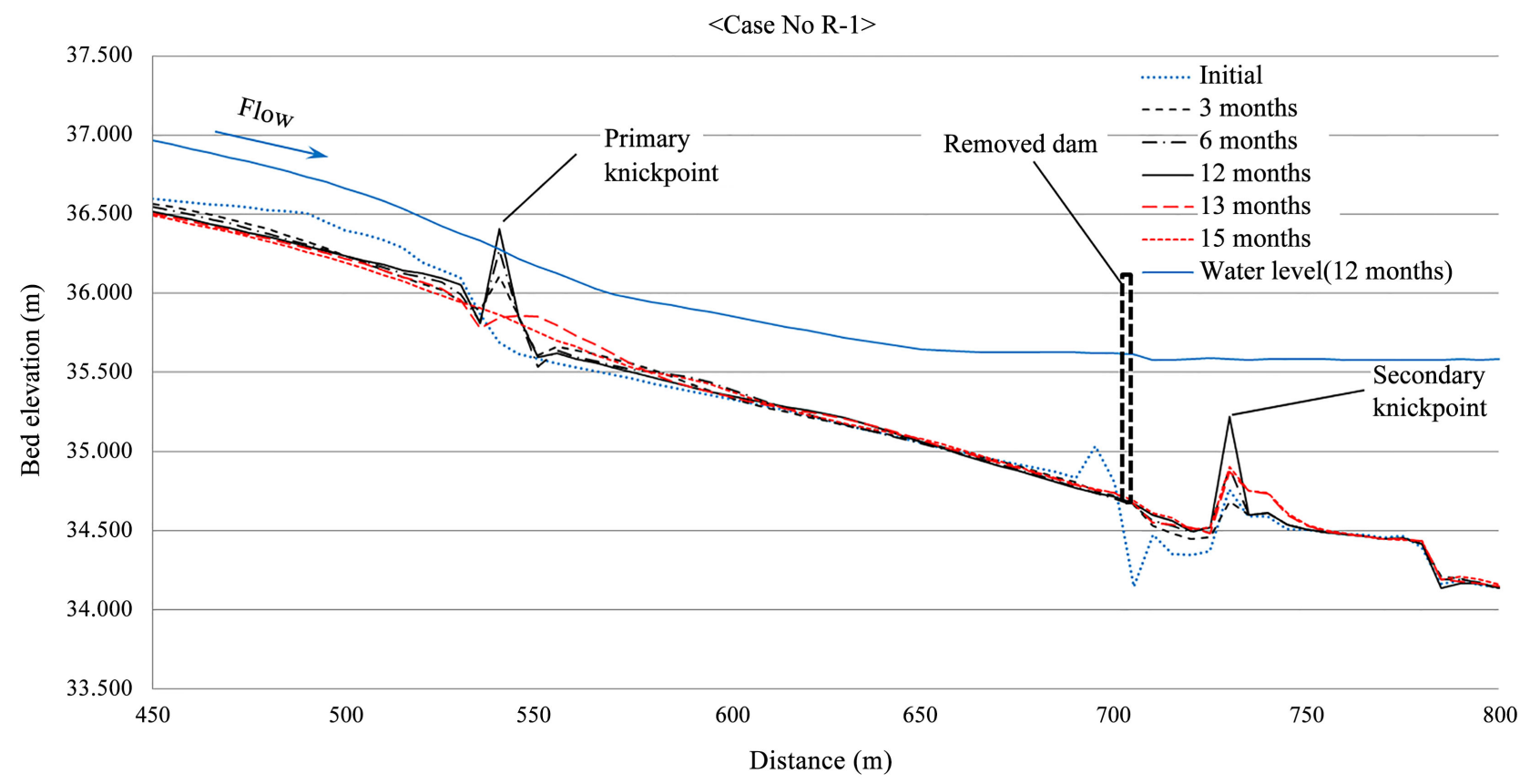

Figure 7. Channel evolution processes following the low-head dam removal.

Figure 8 shows the longitudinal changes of river bed following low-head dam removal. In the case of R-1, a knick point has been formed in the upstream of the removed dam by the deposited sediment. The knickpoint has brought about secondary knickpoint at fore part of the existing depositional bar in downstream of the removed dam (Figure 8(a)). The existing sandbar in downstream has been colonized by both grass type and tree type vegetation before low-head dam removal (Figure 9). After 10 years of low-head dam removal, the extent of sandbar in downstream has been increased and tree type vegetation still remained on the sandbar. The sandbar has been extended to the end of the numerical simulation for 50 years. On the other hand, a knickpoint has not been formed in case R-2 with larger sediment $(5 \mathrm{~mm})$. The existing sandbar has been colonized by grass type vegetation before low-head dam removal. After 10 years of low-head dam removal, the sandbar has been still remained, but the grass type vegetation was eliminated. Since the riparian vegetation on sandbar has been removed, the size of sandbar has been gradually diminished (Figure 8(b)). The case R-3 of lower gradient (1/300) shows that the deposited sediment in the upstream of the removed dam rapidly transported to downstream without a knickpoint formation. The local scour in downstream has been recovered in a year after the low-head dam removal. The channel evolution processes became stable in 10 years after low-head dam removal. The river bed has been restored nearly pre-dam condition in this case, because the scale of deposited sediment in the upstream by dam construction was relatively smaller than other cases (Figure 8(c)). As a result of R-4 case with higher dam height (2.0 m), a knickpoint has been formed in upstream of the removed dam by the deposited sediment. After the low-head dam removal, the deposited sediment in upstream of the removed 
dam slowly transported to downstream with the migration of the knickpoint during 10 years. After 50 years of low-head dam removal, the overall river bed elevation has been increased about $20-30 \mathrm{~cm}$ (Figure 8(d)).

\section{Discussion; Reversibility Following Low-Head Dam Construction and Removal}

Low-head dam removal has been regarded as an effective alternative to restore
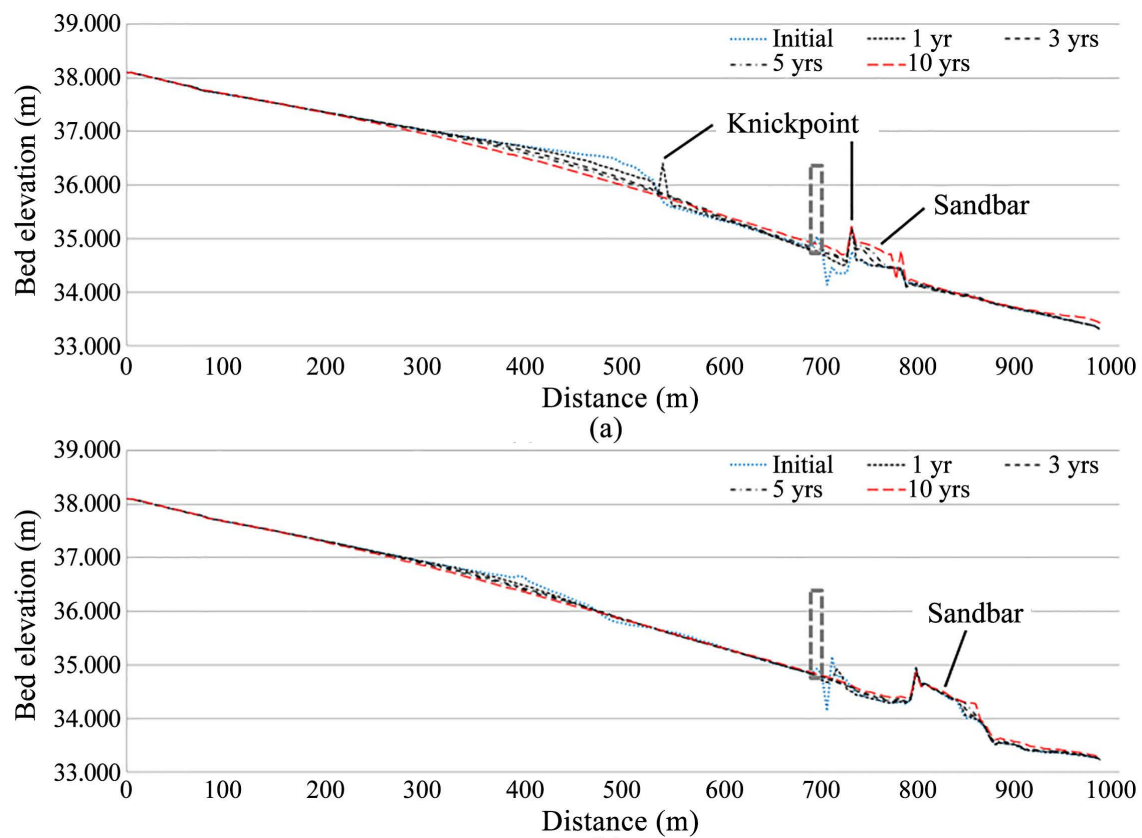

(b)

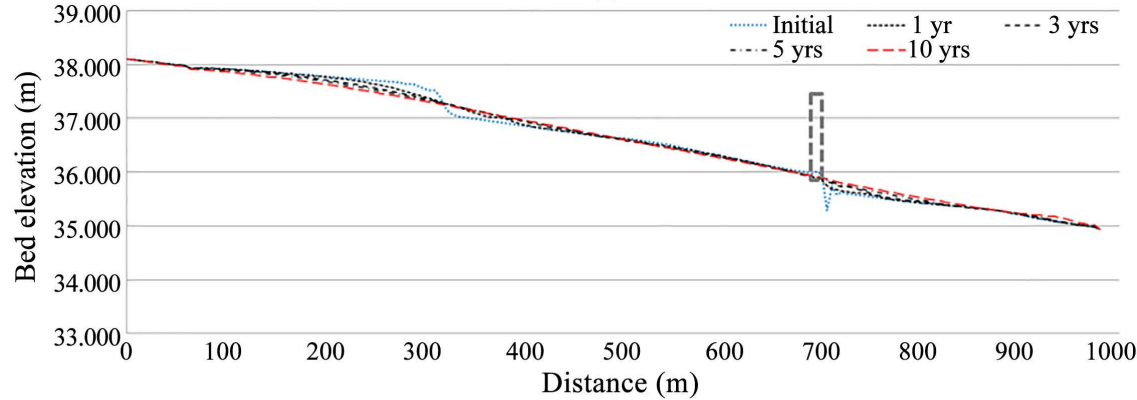

(c)

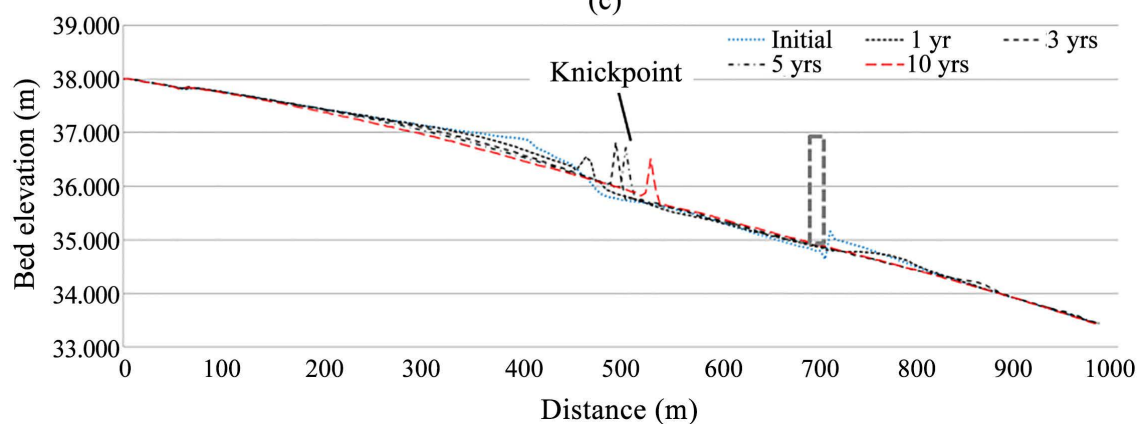

(d)

Figure 8. Longitudinal profile changes following the low-head dam removal. (a) Case No. R-1; (b) Case No. R-2; (c) Case No. R-3; (d) Case No. R-4. 


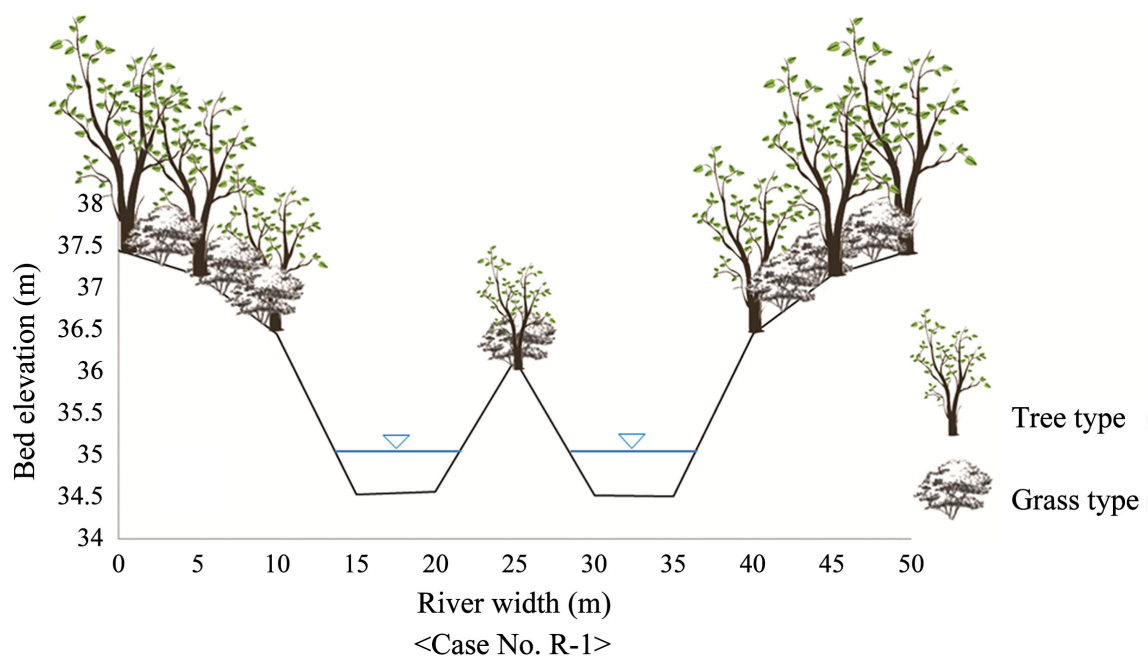

Figure 9. Riparian vegetation distribution with downstream sandbar $(\mathrm{X}=710)$.

river ecosystem. Unlike large dam (more than 15 meters in height), the effects following low-head dam removal have been overlooked with expectation that the river channel will be restored as pre-dam conditions. To clarify the reversibility of river channel following low-head construction and removal, this study performed the comparison analysis for the final results of low-head dam construction (Stage I) and low-head dam removal (Stage II). As a result, the overall bed elevation has been aggrades as $20-30 \mathrm{~cm}$ except the lower gradient case (D-3, R-3) following low-head dam construction and removal. Cases R-1 and R-2 have shown the sandbar formation in downstream of the removed dam with riparian vegetation colonization. The water channels of these 2 cases (R-1, R-2) have had sinuosity after low-head dam removal with sandbar formation changing the straight channel to meandering channel. The case R-1 which had most sediment deposition rates with dam construction has shown the biggest distinction between before low-head dam construction and after low-head dam removal. Meanwhile, the case R-3 with the least sediment deposition rates in the simulation of dam construction has restored near pre-dam conditions. Consequently, the reversibility following low-head dam construction and removal depends on particular parameters which decide the sediment deposition rates in upstream of the low-head dam. In this research, the sediment diameter and river bed slope significantly attribute to increase the sediment deposition rates in upstream of the low-head dam. Moreover, the riparian vegetation settlement and development of tree type plants are crucial for durability of downstream sandbars.

\section{Conclusions}

This study intends to investigate the long-term channel evolution process following low-head dam construction (50 years) and removal (50 years) and to find out the influential parameters (sediment diameter, river bed slope, dam height) for those channel evolution by numerical simulation model. 
The channel evolution following low-head dam removal significantly depends on deposited sediment in the former reservoir. The sediment deposition rates with low-head dam construction affect the knickpoint formation after low-head dam removal. The knickpoint which has nearly vertical drop in channel bed governs the channel evolution processes following low-head dam removal. In addition, settlement of riparian vegetation on the sandbar in downstream of the low-head dam determines the durability of sandbar following low-head dam removal. Particularly, development of tree type vegetation makes the sandbar maintain for 50 years after low-head dam removal. Ultimately, the knickpoint formation by the deposited sediment and riparian vegetation development on sandbars play an important role for fluvial processes following low-head dam removal.

\section{Acknowledgements}

This research was supported by the Korea Institute of Civil Engineering and Building Technology (Project title: Analysis of channel change before and after construction of hydraulic structures, Project number: 20180053-001).

\section{Conflicts of Interest}

The authors declare no conflicts of interest regarding the publication of this paper.

\section{References}

[1] Hart, D.D., Johnson, T.E., Bushaw-Newton, K.L., Horwitz, R.J., Bednarek, A.T., Charles, D.F., Kreeger, D.A. and Velinsky, D.J. (2002) Dam Removal: Challenges and Opportunities for Ecological Research and River Restoration. BioScience, 52, 669-682. https://doi.org/10.1641/0006-3568(2002)052[0669:DRCAOF]2.0.CO;2

[2] Doyle, M.W., Stanley, E.H. and Harbor, J.M. (2003) Channel Adjustments Following Two Dam Removals in Wisconsin. Water Resources Research, 39, 1011-1025. https://doi.org/10.1029/2002WR001714

[3] Hupp, C.R. and Simon, A. (1991) Bank Accretion and the Development of Vegetated Depositional Surfaces along Modified Alluvial Channels. Geomorphology, 4, 111-124. https://doi.org/10.1016/0169-555X(91)90023-4

[4] Osterkamp, W.R. and Hupp, C.R. (2010) Fluvial Process and Vegetation-Glimpses of the Past, the Present, and Perhaps the Future. Geomorphology, 116, 274-285. https://doi.org/10.1016/j.geomorph.2009.11.018

[5] Kim, S.N., Toda, Y. and Tsujimoto, T. (2014) Effects of Low-Head Dam Removal on River Morphology and Riparian Vegetation: A Case Study of Gongreung River. Journal of Water Resource and Protection, 6, 1682-1690. https://doi.org/10.4236/jwarp.2014.618151

[6] Meyer-Peter, E. and Muller, R. (1948) Formulas for Bed Load Transport. Proceedings of 2 nd meeting of the International Association for Hydraulic Structures Research, Delft, 7 June 1948, 39-64.

[7] Hasegawa, K. (1981) Bank-Erosion Discharge Based on a Non-Equilibrium Theory. Transactions of the Japan Society of Civil Engineers, 316, 37-52. https://doi.org/10.2208/jscej1969.1981.316_37 
[8] Toda, T., Kim, S.N. and Tsujimoto, T. (2014) Relation between Sandbar Mode and Vegetation Expansion in Sand-Bed River. Proceedings of River Flow 2014, Lausanne, 3-5 September, 429.

[9] Jensen, P.B. (1932) Die Stoffproduktion der Pflanzen. Fischer.

[10] Yagisawa, J. and Tanaka, N. (2009) Dynamic Growth Model of River Vegetation Considering the Destruction by Floods and Regeneration Process of Trees. Annual Journal of Hydraulic Engineering, 53, 1171-1176.

[11] Lajczak, A. (1996) Modelling the Long-Term Course of Non-Flushed Reservoir Sedimentation and Estimating the Life of Dams. Earth Surface Processes and Landforms, 21, 1091-1107.

https://doi.org/10.1002/(SICI)1096-9837(199612)21:12<1091::AID-ESP653>3.0.CO; 2-2

[12] Cantelli, A., Paola, C. and Parker, G. (2004) Experiments on Upstream-Migrating Erosional Narrowing and Widening of an Incisional Channel Caused by Dam Removal. Water Resources Research, 40, W03304.

https://doi.org/10.1029/2003WR002940

[13] Toniolo, H., Parker, G. and Voller, V. (2007) Role of Ponded Turbidity Currents in Reservoir Trap Efficiency. Journal of Hydraulic Engineering, 133, 579-595. https://doi.org/10.1061/(ASCE)0733-9429(2007)133:6(579)

[14] Csiki, S. and Rhoads, B.L. (2010) Hydraulic and Geomorphological Effects of Run-of-River Dams. Progress in Physical Geography, 34, 755-780. https://doi.org/10.1177/0309133310369435

[15] Robinson, K.M., Bennett, S.J., Casali, J. and Hanson, G.J. (2000) Processes of Headcut Growth and Migration in Rills and Gullies. International Journal of Sediment Research, 15, 69-82.

[16] Pizzuto, J. (2002) Effects of Dam Removal on River form and Process. BioScience, 52, 683-691. https://doi.org/10.1641/0006-3568(2002)052[0683:EODROR]2.0.CO;2

[17] Doyle, M.W., Stanley, E.H., Orr, C.H., Selle, A.R., Sethi, S.A. and Harbor, J.M. (2005) Stream Ecosystem Response to Small Dam Removal: Lessons from the Heartland. Geomorphology, 71, 227-244. https://doi.org/10.1016/j.geomorph.2004.04.011

[18] Sawaske, S.R. and Freyberg, D.L. (2012) A Comparison of Past Small Dam Removals in Highly Sediment-Impacted Systems in the US. Geomorphology, 151-152, 50-58. https://doi.org/10.1016/j.geomorph.2012.01.013

[19] Kim, S., Toda, Y. and Tsujimoto, T. (2015) Geomorphological and Riparian Vegetation Responses Following a Low-Head Dam Removal: A Study Based on Literature Review. International Journal of River Basin Management, 13, 315-324. 